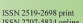

НАУКОВИЙ ВІСНИК

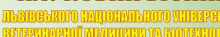

ientific messenger of Lviv National Universit of

and

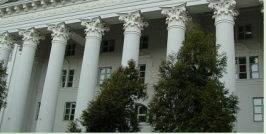

Том 23 № 94 2021
Науковий вісник Дьвівського національного університету ветеринарної медицини та біотехнодогій імені С.3. Гжицького. Серія: Сільськогосподарські науки

\section{Scientific Messenger of Lviv National University} of Veterinary Medicine and Biotechnologies. Series: Agricultural sciences doi: 10.32718/nvlvet-a9402 https://nvlvet.com.ua/index.php/agriculture

UDC 606:637.3:637.055

\title{
The effect of the developed composition of lactic acid bacteria isolated from Carpathian cheese, on the body of laboratory animals
}

\author{
I. I. Kushnir, O. Y. Tsisaryk \\ Stepan Gzhytskyi National University of Veterinary Medicine and Biotechnologies Lviv, Lviv Ukraine
}

Article info

Received 18.01.2021

Received in revised form 22.02 .2021

Accepted 23.02.2021

Stepan Gzhytskyi National University of Veterinary Medicine and Biotechnologies Lviv, Pekarska Str., 50, Lviv, 79010, Ukraine.

Tel.: +38-098-290-16-94 E-mail: irynakushn@gmail.com
Kushnir, I. I., \& Tsisaryk, O. Y. (2021). The effect of the developed composition of lactic acid bacteria isolated from Carpathian cheese, on the body of laboratory animals. Scientific Messenger of Lviv National University of Veterinary Medicine and Biotechnologies. Series: Agricultural sciences, 23(94), 9-15. doi: 10.32718/nvlvet-a9402

Data on the study of the effect of a consortium of lactic acid bacteria on the morphological parameters of blood and the state of the intestinal microflora of white rats using a composition of probiotic strains of $L$. lactis, Lb. plantarum and E. durans SB18 in a ratio of 50:40:10. Thus, when determining the morphological parameters of the blood of rats at 14 days of use found a positive effect of probiotic strains of lactic acid bacteria on the hematopoietic function of laboratory animals. In particular, a significant increase in hemoglobin concentration, erythrocyte count, leukocyte count and hematocrit value was found by 14.9, $14.0,22.5 \%(P<0.05)$ and $5.7 \%$, respectively, compared with the control group. In addition, the use of the drug for 14 days caused an increase in the average concentration of hemoglobin in the erythrocyte $(M C H S)$ by $9.8 \%(P<0.05)$ and a tendency to decrease the average hemoglobin in the erythrocyte $(M C H)$ and the average erythrocyte volume $(M C V)$ by 0.45 and $9.0 \%$, respectively, compared with the control group. Both central and peripheral organs of the immune system were also significantly affected. In particular, the relative weights of the thymus and spleen increased by $21.1(P<0.05)$ and $9.8 \%$ $(P<0.05)$, respectively. When determining the leukogram of peripheral blood of rats, it was found that the use of the study drug in animals of the experimental group caused a tendency to increase the number of neutrophils, lymphocytes and monocytes by 6.0, 0.5 and $19.8 \%$, respectively, with a slight decrease in eosinophils. The use of a composition of a consortium of lactic acid bacteria stimulated an increase in lacto- and bifidobacteria content of the large intestine of white rats. In particular, a significant increase in the number of bifidobacteria and lactobacilli was found by 4.3 and $5.2 \%(P<0.001)$, respectively, relative to the animals of the control group. In addition, 14-day application of the studied composition of probiotic strains contributed to a probable reduction in the number of opportunistic and putrefactive microflora. The number of Escherichia coli, Staphylococcus aureus and fungi of the genus Candida significantly decreased relative to control by $4.7(P<0.01), 2.6(P<0.05)$ and $13.3 \%(P<0.001)$, respectively, all this indicated the recovery of the body of laboratory animals. The positive effect of lactic acid bacteria of the formed composition persists until the 21 st day of the experiment.

Key words: lactic acid bacteria, cheese, laboratory animals, rats, blood.

\section{Вплив розробленої композиції молочнокислих бактерій, виділених із карпатської бринзи, на організм лабораторних тварин}

\author{
I. І. Кушнір, О. Й. Цісарик
}

Львівський національний університет ветеринарної медицини та біотехнологій імені С. 3. Гжицького, м. Львів, Україна

Наведено дані щедо вивчення впливу консорціуму молочнокислих бактерій на морфологічні показники крові та стан мікрофлори кишечнику білих щурів за застосування композиції пробіотичних итамів L. lactis, Lb. plantarum ma E. durans SB18 y cniввidно- 
шенні 50:40:10. Так, при визначенні морфологічних показників крові щурів за 14-добового застосування встановили позитивний вплив пробіотичних штамів молочнокислих бактерій на кровотворну функцію організму лабораторних тварин. Зокрема, виявили вірогідне зростання концентрації гемоглобіну, кількості еритроцитів, кількості лейкоцитів та величини гематокриту відповідно на 14,9, 14,0 22,5\% (P<0,05) та 5,7\% порівняно з величинами контрольної групи. Крім того, застосування препарату упродовж 14 діб викликало зростання середньої кониентрації гемоглобіну в еритроциті (МСНС) на 9,8\% (P < 0,05) та тендениію до зниження середнього вмісту гемоглобіну в еритроциті (МСH) та середнього об'єму еритроцита (МСV) відповідно на 0,45 та 9,0 \% порівняно з показниками контрольної групи. Також суттєвого впливу зазнавали як иентральні, так $i$ периферичні органи імунноі системи. Зокрема, відносні вагові коефіцієнти маси тимуса та селезінки зросли відповідно на 21,1 (P < 0,05) та 9,8 \% (P < 0,05). При визначенні лейкограми периферичної крові шурів було встановлено, щзо застосування досліджуваного препарату у тварин дослідної групи викликало тенденцію до зростання кількості нейтрофілів, лімфоцитів та моночитів відповідно на 6,0, 0,5 та 19,8\% на тлі незначного зниження кількості еозинофілів. Застосування композииї консориіуму молочнокислих бактерій стимулювало збільшення лакто- та біфідобактерій вмісту товстого відділу кишечнику білих шурів. Зокрема, встановили вірогідне збільшення кількості біфідобактерій та лактобактерій відповідно на 4,3 та 5,2 \% (Р< 0,001) щодо тварин контрольної групи. Поряд з ичим 14-добове застосування досліджуваної композииї пробіотичних штамів сприяло вірогідному зменшенню чисельності умовно-патогенної та гнилісної мікрофлори. Кількість киикової палички, золотистого стафілокока та грибів роду Сапдіда вірогідно знижувалась щзодо контролю відповідно на 4,7 (P<0,01), 2,6 (P<0,05) та 13,3\% (P < 0,001), відповідно все це вказувало на оздоровлення організму лабораторних тварин. Позитивний ефект молочнокислих бактерій сформованої композиції зберігається до 21 ї оби експерименту.

Ключові слова: молочнокислі бактерії, бринза, лабораторні тварини, щури, кров.

\section{Ветуп}

Кисломолочні продукти належать до функціональних, оскільки вони позитивно впливають на різноманітні функції макроорганізму, що своєю чергою поліпшує стан здоров'я та знижує ризик розвитку захворювань. Функціональні властивості кисломолочних продуктів забезпечуються не лише внесеними мікроорганізмами, а й тим, що у процесі молочнокислого бродіння продукт набуває нових корисних властивостей (Berezhnyi et al., 2015).

Основними властивостями функціональних кисломолочних продуктів $є$ нормалізація кишкової мікрофлори, вплив на секреторну функцію травних залоз i перистальтику кишечника. Такі продукти пригнічують ріст патогенної, гнильної мікрофлори, стимулюючи ріст нормальної флори, поліпшують всмоктування Кальцію, Фосфору, Магнію, Заліза, мають високу біологічну цінність, містять незамінні амінокислоти, а також вітаміни (Kitchenko, 2014; Berezhnyi et al., 2015). 3 огляду на це сьогодні кисломолочні продукти стали основою для пробіотичних продуктів (Bolhova, 2015).

Дослідженнями встановлено, що включення до раціону дітей кисломолочних продуктів активно коригує стан мікробіоценозу кишечнику, внаслідок чого збільшується кількість лакто- та біфідобактерій та зменшується кількість умовно-патогенної мікрофлори за рахунок антагоністичного впливу молочнокислих бактерій (Rodionov et al., 2014).

Крім того, доведено, що різні штами молочнокислих бактерій, зокрема Lactobacillus plantarum, можливо використовувати у м'ясній промисловості як біологічний бар'єр, що дозволить уповільнити розвиток патогенної мікрофлори (Vinnikova et al., 2015). При цьому біологічна ефективність пробіотичних препаратів визначається не лише властивостями використаних штамів мікроорганізмів, а й технологією їх отримання, де головним і вкрай важливим є досягнення максимального виходу життєздатних клітин бактерій i синтезованих біологічно активних речовин (Safronova, 2015).

Сучасні дослідження показали, що вплив пробіотиків на макроорганізм складний та багатогранний.
Так, молочнокислі бактерії підвищують захисні та посилюють бар'єрні властивості епітелію кишечнику, конкурують у просвіті кишечнику з патогенними та умовно-патогенними мікроорганізмами, проявляють імуномодулювальний ефект, зокрема впливають на гуморальний і клітинний імунітет. Крім того, активують клітини Т-кілери, В-лімфоцити, печінкові, перитонеальні макрофаги та мононуклеарні фагоцити (Nastoyaschaya et al., 2011; Kryvoshlyk et al., 2011; Kornienko \& Netrebenko, 2016). При цьому імуномодулювальний ефект залежав від тривалості їхного застосування. Зокрема, після семидобового застосування виявляли лише часткове збільшення кількості макрофагів та підвищення показників їхньої поглинальної активності, а значне зростання значень цих показників починалося 314 доби і тривало до 21 доби (Nastoyaschaya et al., 2011).

Позитивна дія пробіотиків полягає в тому, що вони інгібують ріст патогенних мікроорганізмів завдяки синтезу антимікробних речовин, вступають у конкуренцію з ними за поживні речовини та рецептори адгезії, сприяють відновленню та оптимізації функціонування біоплівки, що вистилає слизову кишечнику та стимулюють ріст індигенної флори в результаті продукування вітамінів та інших факторів, нормалізують $\mathrm{pH}$ середовища, нейтралізують різні ксенобіотики (Hyrobokov et al., 2009). Важливою перевагою пробіотиків, на відміну від антибіотиків, є те, що вони не викликають утворення стійкості до них бактерій (Dinleyici et al., 2012; Vitetta et al., 2014) та не пригнічують імунітет, а стимулюють вироблення антитіл і неспецифічних факторів резистентності (Serebryakova, 2014; Ashraf \& Shah, 2014).

Нормальна мікрофлора підтримує біохімічну, метаболічну та імунну рівновагу організму господаря, необхідну для збереження його здоров'я і $є$ важливим фактором загального гомеостазу організму (Shirina et al., 2013).

Зміна рівноваги мікрофлори кишечнику, викликана використанням антибіотиків та інших стресових факторів, призводить до порушення мікробіоценозу організму, що виражається в зміні конкурентного відношення мікроорганізмів, збільшення числа умов- 
но-патогенних бактерій та зміні метаболічної активності нормофлори (Makarenko et al., 2016).

Крім імуномодулювальної дії пробіотиків встановлено також i позитивний вплив на морфологічні показники крові, зокрема, при застосуванні пробіотиків на основі молочнокислих бактерій підвищувався вміст гемоглобіну, кількість еритроцитів та лейкоцитів у крові піддослідної птиці (Lysenko et al., 2008).

Проте варто враховувати, що пробіотичні мікроорганізми не можуть тривалий час виживати у біотопах людини і тому їхня фізіологічна роль $є$ транзитною. Основна функція пробіотичної терапії полягає у відновленні мікробного балансу та функцій індигенної мікрофлори, в тому числі запобіганні адгезії патогенних мікроорганізмів (Huzhvynska et al., 2009; Tkach \& Puchkov, 2014).

Власне тому вивчення кишкового мікробіоценозу $\epsilon$ надзвичайно актуальною темою, оскільки мікробіома людини як у здоровому стані, так і за різних патологічних станів тісно пов'язана $з$ організмом господаря (Hubska et al., 2019).

Тому метою роботи було вивчити вплив молочнокислих бактерій розробленої композиції (Kushnir et al., 2020) на морфологічні показники крові та стан мікрофлори кишечнику білих щурів за їх застосування.

\section{Матеріал і методи досліджень}

Визначення впливу досліджуваної композиції консорціуму молочнокислих бактерій на організм лабораторних тварин проводили на білих щурах, лінії Вістар, масою тіла 160-180 г. 3 цією метою було сформовано за принципом аналогів контрольну та дослідну групи тварин по шість тварин у кожній. Тваринам першої (контрольної) групи застосовували ізотонічний розчин натрію хлориду, тваринам другої групи вводили композицію пробіотичних штамів L. lactis, Lb. plantarum та E. durans SB18 у співвідношенні 50:40:10 в дозі $1 \mathrm{~cm}^{3}\left(1 \cdot 10^{7} \mathrm{KУО} / \mathrm{cm}^{3}\right)$ на тварину. Досліджувану композицію вводили внутрішньошлунково за допомогою металевого зонда упродовж 21 діб.

3 метою вивчення гематологічних показників і вагових коефіцієнтів маси внутрішніх органів за застосування досліджуваної композиції лабораторних тварин на 14 та 21 доби експерименту декапітували за умов легкого ефірного наркозу та проводили відбір крові (Elizarova et al., 1974).

У крові визначали: концентрацію гемоглобіну гемоглобінціанідним методом (з ацетонціангідрином) (Kondrahin et al., 1985); кількість еритроцитів та лейкоцитів - шляхом підрахунку на сітці Горяєва лічильної камери; лейкограму - шляхом мікроскопічної оцінки сухих, фіксованих метиловим спиртом та пофарбованих барвником Романовського-Гімзи мазків крові (Kondrahin et al., 1985).

Для вивчення впливу досліджуваної композиції консорціуму пробіотичних штамів на мікрофлору товстого відділу кишечнику проводили мікробіологі- чне дослідження проб вмісту на 21 добу експерименту. Для цього проводили послідовні десятикратні розведення проб з подальшим висіванням матеріалу на селективні живильні середовища. У вмісті товстого відділу кишечнику визначали кількість $E$. coli, S. aureus, Lactobacillus spp., Bifidobacterium spp. та грибів роду Candida.

Кількість мікроорганізмів в 1 г вихідного матеріалу (C) розраховували за формулою:

$$
\mathrm{C}=(\mathrm{N}: \mathrm{V}) \cdot \mathrm{K}
$$

де: $\mathrm{N}$ - середня кількість колоній в одній чашці; $\mathrm{V}$ - об'єм суспензії, що вноситься при посіві; $\mathrm{K}$ - кратність розведення.

Ідентифікацію мікроорганізмів проводили загальновизнаними методами 3 використанням визначника бактерій Берджі (Houlta et al., 1997).

Отримані результати обробляли статистично із визначенням середніх величин, достовірного інтервалу при наявному рівні значущості $\mathrm{P}<0,053$ урахуванням критерію Стьюдента.

\section{Результати та їх обговорення}

Попередніми дослідженнями (Kushnir et al., 2020) встановлено, що композиція Lactococcus lactis, Lactobacillus plantarum та Enterococcus durans SB18 у співвідношенні 50:40:10 за температури культивування 32 та $37{ }^{\circ} \mathrm{C}$ була найоптимальнішою для іï залучення як пробіотичного препарату, тому надалі вивчали вплив на морфологічні показники крові та мікрофлору кишечнику лабораторних тварин за тривалого застосування.

При визначенні морфологічних показників крові щурів за 14-добового застосування встановили, що композиція пробіотичних штамів молочнокислих бактерій позитивно впливала на кровотворну функцію організму лабораторних тварин. Так, при визначенні впливу консорціуму мікроорганізмів на гематологічні показники (табл. 1) встановлено вірогідне зростання концентрації гемоглобіну на 14,9\% (P < 0,05), кількості еритроцитів на $14,7 \%(\mathrm{P}<0,05)$, кількості лейкоцитів на $22,5 \%(\mathrm{P}<0,05)$ та величини гематокриту на 5,7 \% порівняно 3 величинами контрольної групи. Крім того, було встановлено, що застосування препарату упродовж 14 діб викликало зростання середньої концентрації гемоглобіну в еритроциті (МСHC) на 9,8 \% $(\mathrm{P}<0,05)$ та тенденцію до зниження середнього вмісту гемоглобіну в еритроциті $(\mathrm{MCH})$ та середнього об'єму еритроцита (MCV) відповідно на 0,45 та 9,0\% порівняно з показниками контрольної групи.

При визначенні лейкограми периферичної крові щурів було встановлено, що застосування досліджуваного препарату в тварин дослідної групи викликало тенденцію до зростання кількості нейтрофілів, лімфоцитів та моноцитів відповідно на 6,0, 0,5 та 19,8 \% на тлі незначного зниження кількості еозинофілів. 
Таблиця 1

Гематологічні показники тварин на14 добу експерименту

\begin{tabular}{lrc}
\hline \multicolumn{1}{c}{ Показники } & \multicolumn{2}{c}{ Групи тварин } \\
\cline { 2 - 3 } & Контроль & Дослід \\
\hline Гемоглобін, г/л & $143,0 \pm 5,19$ & $164,3 \pm 2,33^{*}$ \\
Еритроцити, Т/л & $6,45 \pm 0,26$ & $7,40 \pm 0,14^{*}$ \\
Лейкоцити, Г/л & $14,2 \pm 0,82$ & $17,4 \pm 0,69^{*}$ \\
Гематокрит, \% & $36,7 \pm 0,66$ & $37,5 \pm 0,55$ \\
МСН, пг & $22,3 \pm 1,67$ & $22,2 \pm 0,15$ \\
МСНС, г/дл & $38,9 \pm 0,78$ & $42,7 \pm 0,59 *$ \\
МСV, мкм & $57,2 \pm 2,30$ & $52,03 \pm 0,93$ \\
Еозинофіли, \% & $2,66 \pm 0,88$ & $0,33 \pm 0,33$ \\
Нейтрофіли, \% & $28,3 \pm 2,19$ & $30,0 \pm 2,0$ \\
Лімфоцити, \% & $67,3 \pm 1,86$ & $67,7 \pm 1,45$ \\
Мононити, \% & $1,67 \pm 0,33$ & $2,00 \pm 0,58$ \\
\hline
\end{tabular}

Примітка: *-P <0,05

3 метою оцінки функціонального стану організму лабораторних тварин за дії композиції пробіотичних штамів визначили вагові коефіцієнти маси внутрішніх органів (табл. 2). У результаті проведених досліджень встановили, що на 14 добу експерименту суттєвого впливу зазнавали як центральні, так і периферичні органи імунної системи. Зокрема, відносні вагові коефіцієнти маси тимуса та селезінки зросли відповідно на 21,1 (P < 0,05) та 9,8 \% $(\mathrm{P}<0,05)$. Виявлені зміни можуть вказувати на самооновлення імунної системи та активування взаємодії імунокомпетентних клітин, оскільки в тимусі проходять процеси проліферації клітин-попередників та їх диференціювання і дозрівання, а у селезінці - формування специфічної імунної відповіді. Також виявляли, що застосування досліджуваної композиції викликало зростання вагового коефіцієнту маси печінки на $18,1 \%$ ( $<<0,05)$, порівняно 3 величинами контрольної групи, що, очевидно, може вказувати на підвищення білковосинтезувальної функції печінки. Змін відносних вагових коефіцієнтів маси легень, серця, та нирок не виявили. Крім того, 14-добове застосування досліджуваного засобу викликало зростання маси тіла на $7,6 \%$.

\section{Таблиця 2}

Вагові коефіцієнти маси внутрішніх органів білих щурів на 14 добу експерименту

\begin{tabular}{lcc}
\hline \multicolumn{1}{c}{ Показники } & \multicolumn{2}{c}{ Групи тварин } \\
\cline { 2 - 3 } & Контроль & Дослід \\
\hline Печінка & $29,3 \pm 0,26$ & $34,6 \pm 1,21^{*}$ \\
Легені & $10,8 \pm 0,16$ & $10,3 \pm 0,67$ \\
Серце & $3,61 \pm 0,098$ & $3,35 \pm 0,16$ \\
Селезінка & $4,29 \pm 0,10$ & $4,71 \pm 0,05^{*}$ \\
Нирка права & $3,74 \pm 0,07$ & $3,75 \pm 0,22$ \\
Нирка ліва & $3,41 \pm 0,15$ & $3,84 \pm 0,16$ \\
Тимус & $1,99 \pm 0,07$ & $2,41 \pm 0,11^{*}$ \\
Маса тіла, Г & $195,2 \pm 5,33$ & $210,0 \pm 2,31$ \\
Примітка: ${ }^{*}-\mathrm{P}<0,05, * *-\mathrm{P}<0,01, * * *-\mathrm{P}<0,0001$ &
\end{tabular}

Застосування композиції молочнокислих бактерій позитивно впливало на нормофлору кишечнику лабораторних тварин (табл. 3), зокрема стимулювало збільшення лакто- та біфідобактерій вмісту товстого відділу кишечнику білих щурів. Так, встановили вірогідне збільшення кількості біфідобактерій та лактобактерій відповідно - на 4,3 та 5,2 (P < 0,001) щодо тварин контрольної групи. Також варто зауважити, що на 14 добу експерименту застосування досліджуваної композиції сприяло вірогідному зменшенню чисельності умовно-патогенної та гнилісної мікрофлори. Кількість кишкової палички, золотистого стафілокока та грибів роду Candida вірогідно знижувалась щодо контролю на 4,7 (P < 0,01), 2,6 (P < 0,05) та 13,3\% $(\mathrm{P}<0,001)$ відповідно, все це вказувало на оздоровлення організму лабораторних тварин.
Надалі проводили вивчення впливу препарату на організм лабораторних тварин за застосування консорціуму молочнокислих бактерій упродовж 21 доби.

При визначенні гематологічних показників (табл. 4) встановили, що на 21 добу застосування досліджуваних пробіотичних штамів залишалася тенденція до зростання концентрації гемоглобіну на $8,1 \%$, кількості еритроцитів та лейкоцитів відповідно на 8,3 та $4,5 \%$, а величини гематокриту лише на $1,0 \%$. Крім того, було встановлено, що застосування препарату упродовж 21 доби викликало зростання середнього вмісту гемоглобіну в еритроциті (МCH) та середньої концентрації гемоглобіну в еритроциті (MCHC) відповідно на 0,5\% та 6,1\% (P < 0,05) на тлі зниження середнього об'єму еритроцита (MCV) на 6,4 \% порівняно з величинами контрольної групи. 
Таблиця 3

Вплив консорціуму молочнокислих бактерій на мікрофлору кишечнику білих щурів на 14 добу експерименту

\begin{tabular}{|c|c|c|}
\hline \multirow{2}{*}{ Мікроорганізми } & \multicolumn{2}{|c|}{ Кількість КУО/г, log } \\
\hline & Контроль & Дослід \\
\hline Біфідобактерії & $8,53 \pm 0,02$ & $8,90 \pm 0,01 * * *$ \\
\hline Лактобактерії & $9,89 \pm 0,02$ & $10,41 \pm 0,05 * * *$ \\
\hline Кишкова паличка & $5,86 \pm 0,01$ & $5,58 \pm 0,02 * * *$ \\
\hline S.aureus & $5,64 \pm 0,02$ & $5,49 \pm 0,02 *$ \\
\hline Гриби роду Candida & $6,88 \pm 0,01$ & $5,96 \pm 0,01 * * *$ \\
\hline
\end{tabular}

Примітка: *-P <0,05, **-P <0,01,***-P $<0,001$

При визначенні морфологічного складу лейкоцитів периферичної крові щурів було встановлено, що застосування досліджуваного препарату в тварин дослі- дної групи викликало тенденцію до зростання кількості лімфоцитів на 19,2 \% на тлі незначного зниження кількості нейтрофілів, моноцитів та еозинофілів.

\section{Таблиця 4}

Гематологічні показники тварин на 21 добу експерименту

\begin{tabular}{|c|c|c|}
\hline \multirow{2}{*}{ Показники } & \multicolumn{2}{|c|}{ Групи тварин } \\
\hline & Контроль & Дослід \\
\hline Гемоглобін, г/л & $145,3 \pm 2,03$ & $157,0 \pm 3,61$ \\
\hline Еритроцити, Т/л & $6,66 \pm 0,32$ & $7,21 \pm 0,45$ \\
\hline Лейкоцити, Г/л & $13,2 \pm 1,42$ & $13,8 \pm 2,11$ \\
\hline Гематокрит, \% & $38,5 \pm 1,04$ & $38,9 \pm 1,10$ \\
\hline $\mathrm{MCH}, \Pi \Gamma$ & $21,8 \pm 0,87$ & $21,9 \pm 1,24$ \\
\hline $\mathrm{MCHC,} \mathrm{г/дл}$ & $37,8 \pm 0,50$ & $40,1 \pm 0,49^{*}$ \\
\hline $\mathrm{MCV}$, мкм $^{3}$ & $57,9 \pm 1,49$ & $54,2 \pm 2,17$ \\
\hline Еозинофіли, \% & $1,67 \pm 1,20$ & $1,33 \pm 0,33$ \\
\hline Нейтрофіли, \% & $34,7 \pm 4,06$ & $25,0 \pm 9,54$ \\
\hline Лімфоцити, \% & $61,0 \pm 4,04$ & $72,7 \pm 9,87$ \\
\hline Мононити, \% & $2,67 \pm 0,88$ & $1,0 \pm 0,0$ \\
\hline
\end{tabular}

При визначенні функціонального стану організму лабораторних тварин за 21-добового застосування композиції пробіотичних штамів (табл. 5) виявили тенденцію до зростання вагових коефіцієнтів маси печінки на 4,4 \%, тимуса на 5,2 \%, а маси тіла тварин на $4,6 \%(\mathrm{P}<0,05)$ порівняно 3 величинами контрольної групи. Поряд 3 цим встановлено, що застосування досліджуваного препарату не спричинило вірогідних змін маси легень, серця, селезінки, нирок.

Таблиця 5

Вагові коефіцієнти маси внутрішніх органів білих щурів за застосування на 21 добу експерименту

\begin{tabular}{lrc}
\hline \multicolumn{1}{c}{ Показники } & \multicolumn{2}{c}{ Групи тварин } \\
\cline { 2 - 3 } & Контроль & Дослід \\
\hline Печінка & $38,8 \pm 1,21$ & $40,5 \pm 1,68$ \\
Легені & $8,24 \pm 0,32$ & $7,69 \pm 0,48$ \\
Серце & $3,46 \pm 0,12$ & $3,57 \pm 0,10$ \\
Селезінка & $5,15 \pm 0,64$ & $5,07 \pm 0,22$ \\
Нирка права & $3,50 \pm 0,09$ & $3,27 \pm 0,04$ \\
Нирка ліва & $3,58 \pm 0,09$ & $3,51 \pm 0,13$ \\
Тимус & $1,94 \pm 0,06$ & $2,04 \pm 0,15$ \\
Маса тіла, $\Gamma$ & $207,2 \pm 0,70$ & $216,7 \pm 2,17 *$ \\
Примітка: $*$ - $<<0,05, * *-\mathrm{P}<0,01 * * *-\mathrm{P}<0,0001$ &
\end{tabular}

На 21 добу застосування композиції молочнокислих бактерій позитивний вплив на нормофлору кишечнику лабораторних тварин зберігався (табл. 6). Зокрема, на тлі значного збільшення у вмісті товстого відділу кишечнику білих щурів лактобактерій на 5,8 \% (Р < 0,001) кількість біфідобактерій зросла на
4,4 \% (P < 0,001) порівняно з 14 добою. Проте значно зменшувалась чисельність умовно-патогенної та гнилісної мікрофлори. Так, кількість кишкової палички, золотистого стафілокока та грибів роду Candida вірогідно знижувалась щодо контролю на 6,1 ( $<<0,01)$, $2,9(\mathrm{P}<0,05)$ та $13,5 \%$ ( $<0,001)$ відповідно. 


\section{Таблищя 6}

Вплив консорціуму молочнокислих бактерій на мікрофлору кишечнику білих щурів на 21 добу експерименту

\begin{tabular}{lcc}
\hline \multicolumn{1}{c}{ Мікроорганізми } & \multicolumn{2}{c}{ Кількість КУО/г, log } \\
\cline { 2 - 3 } & Контроль & Дослід \\
\hline Біфідобактерії & $8,57 \pm 0,02$ & $8,95 \pm 0,01^{* * *}$ \\
Лактобактерії & $9,89 \pm 0,02$ & $10,47 \pm 0,05^{* * *}$ \\
Кишкова паличка & $5,88 \pm 0,03$ & $5,52 \pm 0,04^{* *}$ \\
S.aureus & $5,69 \pm 0,02$ & $5,52 \pm 0,02^{*}$ \\
Гриби роду Candida & $6,86 \pm 0,01$ & $5,93 \pm 0,02^{* * *}$ \\
\hline
\end{tabular}

Примітка: *-P <0,05, **-P <0,01,***- $\mathrm{P}<0,001$

Таким чином, можна стверджувати, що молочнокислі бактерії сформованого консорціуму виявили позитивний вплив на організм щурів. Цей вплив базується на різносторонніх біологічних ефектах пробіотичних штамів, зокрема, Enterococcus durans SB18 нормалізації $\mathrm{pH}$, здатності синтезувати біологічно активні речовини, як от вітаміни, органічні кислоти, амінокислоти (Kushnir et al., 2020), антагоністичній активності (Kushnir et al., 2020) та здатності виживати в умовах низьких значень $\mathrm{pH}$ та високих концентрацій жовчі (Kushnir, 2020).

\section{Висновки}

1. Застосування консорціуму молочнокислих бактерій L. lactis, Lb. plantarum та E. Durans SB18 у співвідношенні 50:40:10 позитивно впливала на кровотворну функцію організму лабораторних тварин. Зокрема на 14 добу експерименту вірогідно зростає концентрація гемоглобіну, кількість еритроцитів та лейкоцитів відповідно на 14,9, 22,8 та 4,5\% (P < 0,05) а також величина гематокриту на $2,2 \%$ порівняно 3 величинами контрольної групи.

2. Молочнокислі бактерії сформованої композиції здійснили позитивний вплив на центральні та периферичні органи імунної системи, відносні вагові коефіцієнти маси тимуса і селезінки зросли відповідно на 21,1 (P < 0,05) та 9,8 \% ( зберігалась і на 21 добу експерименту.

3. Застосування консорціуму молочнокислих бактерій, виділених з традиційної карпатської бринзи, позитивно впливало на нормофлору кишечника лабораторних тварин. Так, на 14 добу експерименту вірогідно збільшується кількість лакто- та біфідобактерії вмісту товстого відділу кишечника білих щурів відповідно на 4,3 та 5,2 \% (P < 0,001) та тлі вірогідного зниження кількості кишкової палички, золотистого стафілокока та грибів роду Candida відповідно на 4,7 $(\mathrm{P}<0,01), 2,6(\mathrm{P}<0,05)$ та 13,3\% $(\mathrm{P}<0,001)$ щодо тварин контрольної групи.

\section{References}

Ashraf, R., \& Shah, N. P. (2014). Immune system stimulation by probiotic microorganisms. Crit. Rev. Food Sci. Nutr, 54(7), 938-956. doi: 10.1080/10408398.2011.619671.

Berezhnyi, V. V., Drokh, H. V., \& Bondarets, Yu. I. (2015). Vykorystannia kyslomolochnykh produktiv funktsionalnoho kharchuvannia u praktytsi likariv- pediatriv ta likariv zahalnoi praktyky - simeinykh likariv. Sovremennaia pedyatryia, 8, 82-87 (in Ukrainian).

Bolhova, N. V. (2015). Pidkhody do stvorennia funktsionalnykh molochnykh produktiv. Tekhnolohyy XXI veka: sb. tezysov po mater. XXI Mezhdunar. nauch. konf. (8-10 sentiabria 2015 h.). Hlukhov, 1, 27-28 (in Ukrainian).

Dinleyici, E. C., Dalgic, N., Guven, S., Ozen, M. et al. (2012). The effect of a multispecies synbiotic mixture on the duration of diarrhea and length of hospital stay in children with acute diarrhea in Turkey: single blinded randomized study. European Journal of Pediatrics, 172(4), 459-464. doi: 10.1007/s00431012-1903-5.

Elizarova, O. N., Zhidkova, L. V., \& Kochetkova, T. A. (1974). Posobie po toksikologii dlja laborantov. M.: Medicina (in Russian).

Houlta, D., Kryha, N., \& Snyta, P. (1997). Opredelitel' bakterij Berdzhi. M. Mir, 1, 2 (in Russian).

Hubska, O. Yu., Kuzminetes, A. A., Hutsul, V. M., \& Lavrenchuk, I. O. (2019). Intestinal microbiome and osteoarthritis. Gastroenterologìa, 53(2), 132-137. doi: 10.22141/2308-2097.53.2.2019.168988.

Huzhvynska, S. O., Breslavets, V. O., Stehnii, B. T., \& Sukharev, Yu. S. (2009). Probiotic for the prevention of dysbiotic disturbances of bird. "Actual problems of modern poultry". Materials of the X Ukrainian Conference on Poultry Production with International Participation. Kharkiv, 46-59 (in Ukrainian).

Hyrobokov, V. P., Yankovskyi, D.,S., \& Dyment, H. S. (2009). Mikrobna ekolohiia liudyny z kolorovym atlasom. Navch. Posibnyk (in Ukrainian).

Kitchenko, L. M. (2014). Funktsionalni kyslomolochni produkty pokrashchat zdorovia spozhyvacha. Visnyk Sumskoho natsionalnoho ahrarnoho universytetu. Seriia Tvarynnytstvo, 2/1(24), 48-152 (in Ukrainian).

Kondrahin, I. P., Kurilov, N. V., \& Malahov, A. G. (1985). Klinicheskaja laboratornaja diagnostika V veterinarii. M.: Agropromizdat (in Russian).

Kopcha, V. S. (2009). Antybiotykorezystentnist probiotykiv: rozdumy i fakty. Infektsiini khvoroby, 1, 76-80. doi: 10.11603/1681-2727.2009.1.756 (in Ukrainian).

Kornienko, E. A., \& Netrebenko, O. K. (2016). Probiotics: action mechanisms and indications according to international recommendations in pediatrics. Pedyatryia. Zhurnal im. H. N. Speranskoho, 95(1), 108-121. URL: https://cyberleninka.ru/article/n/probiotiki- 
mehanizmy-deystviya-i-pokazaniya-v-sootvetstvii-smezhdunarodnymi-rekomendatsiyami-v-pediatrii (in Russian).

Kryvoshlyk, M. O., Nastoiashcha, N. I., Sakhniuk, O. M., Surmasheva O. V., Kirsanova, O. S., Putiienko, R. V., \& Nikonova, N. O. (2011). Eksperymentalne vyvchennia imunostymuliuiuchoi dii etalonnoho shtamu. Dovkillia ta zdorovia, 3(58), 53-57. URL: https://cyberleninka.ru/article/n/eksperimentalnevivchennya-imunostimulyuyuchoyi-diyi-etalonnogoshtamu-bifidobakteriy (in Ukrainian).

Kushnir, I. I. (2020). Vplyv pH i riznyh koncentracij soli ta zhovchi na rist enterokokiv, vydilenyh z pryrodnyh ekonish. Zbirnyk naukovyh prac' "Tehnologija vyrobnyctva i pererobky produkcii' tvarynnyctva", 2, 76-81. doi: 10.33245/2310-9270-2020-158-2-76-81.

Kushnir, I. I., Tsisaryk, O. Y., Kushnir, I. M., Semen, I. S., Slyvka, I. M., \& Musiy, L. Y. (2020). Properties of formed compositions of probiotic strains isolated from Carpathian bryndza. Scientific Messenger of Lviv National University of Veterinary Medicine and Biotechnologies. Series: Agricultural sciences, 22(93), 119-125. doi: 10.32718/nvlvet-a9320.

Kushnir, I. I., Tsisaryk, O. Y., Shalovylo, S. H., Gutyj, B. V., Kushnir, G. V., Slyvka, I. M., \& Musiy, L. Y. (2020). The ability of enterococci extracted from traditional Carpathian cheese bryndza to produce biologically active substances. Ukrainian Journal of Veterinary and Agricultural Sciences, 3(3), 15-19. doi: 10.32718/ujvas3-3.03.

Kushnir, I. I., Tsisaryk, O. Y., Slyvka, I. M., Musiy, L. Y., Kushnir, I. M., \& Semen, I. S. (2020). Growth intensity and antibacterial properties of Enterococcus faecium and Enterococcus durans strains isolated from traditional Carpathian brynza Scientific Messenger of Lviv National University of Veterinary Medicine and Biotechnologies. Series: Agricultural Sciences, 22 (92), 42-49. doi: 10.32718/nvlvet-a9208.

Lysenko, S., Vasil'ev, A., \& Sochinskaja, O. (2008). Ispol'zovanie probiotikov posle antibiotikov. Pticevodstvo, 10, 42-43 (in Russian).

Makarenko, O. M., Petrov, P. I., \& Lugina, S. V. (2016). Suchasnyy pohlyad na problemu profilaktyky ta likuvannya dysbakteriozu. Aktualni problemy suchasnoi medytsyny: Visnyk ukrainskoi medychnoi stomatolohichnoi akademii, 16(2), 294-300. URL: http://nbuv.gov.ua/UJRN/apsm_2016_16_2_68 (in Ukrainian).

Nastoyaschaya, N. I., Sakhnyuk, O. N., Krivoshlik, M. A., Surmasheva, H. V., Kirsanova, A. S., \& Putiyenko R. V. (2011). Immunostimulating activity of probiotic preparations of lactobacilli. Laboratorna diahnostyka, 2(56), 26-31. URL: http://nbuv.gov.ua/UJRN/ labdiag_2011_2_7.

Rodionov, V. P., Matviienko, I. M., Kvashnina, L. V., \& Kravchenko, O. M. (2014). Vplyv kyslomolochnoi produktsii na mikrobiotsenoz ta mistsevyi imunitet kyshechnykau ditei rannoho viku: rezultaty doslidzhennia. Sovremennaia pedyatryia, 1(57), 113121. URL: http://nbuv.gov.ua/UJRN/perynatology 2014_1_11 (in Ukrainian).

Safronova, L. A. (2015). Probiotychni vlastyvosti bakterii rodu Bacillus i vzaiemodiia preparativ na yikh osnovi z makroorhanizmom [Tekst]: avtoref. dys. ... d-ra biol. nauk : 03.00.07; NAN Ukrainy, In-t mikrobiolohii i virusolohii im. D. K. Zabolotnoho. Kyiv (in Ukrainian).

Serebryakova, E. N. (2014). Probiotics for Prevention and Treatment of Diarrhea in Children. Trudnyi patsiyent, 12(5), 20-24. URL: https://t-pacient.ru/articles/8227 (in Russian).

Shirina, A. A., Petenko, A. I., Lysenko, Ju. A., i dr. (2013). Farmakologicheskoe obosnovanie primenenija probiotika "Promomiks S". Pticevodstvo, 9, 35-39 (in Russian).

Tkach, S. M., \& Puchkov, K. S. (2014). The role of probiotics in correction of alterations of gut microbiota. J. Modern Gastroenterol., 3(77), 59-65. URL: http://nbuv.gov.ua/UJRN/SGastro_2014_3_12.

Vinnikova, L. H., Yamborko, H. V., \& Kyshenia, A. V. (2015). Vplyv molochnokyslykh bakterii na poverkhnevu mikrobiotu miasa. Determine the effect of lacticacidba cteriaon the surface micro flora of meat. The journal Food Science and Technology, 9(3), 3135. doi: 10.15673/2073-8684.3/2015.50278.

Vitetta, L., Briskey, D., Alford, H., Hall, S., \& Coulson, S. (2014). Probiotics, prebiotics and the gastrointestinal tract in health and disease. Inflammopharmacology, 2(3), 135-154. doi: 10.1007/s10787-014-0201-4. 